\title{
THE EMERGENCE OF COMPETITIVE PARTY SYSTEMS: COMPARATIVE OBSERVATIONS ON THE CUSTODIAL PARTY PERIOD IN THE UNITED STATES, SRI LANKA AND CANADA
}

\author{
By Calvin A. Woodward
}

Competitive party environments have only rarely endured in decolonized polities. Burdened by the strenuous and complicated task of nation-building, new nations have tended, almost compulsively, to institute authoritarian political systems. Often in these societies, instability and the perception of a more manageable system of control have contributed to the assumption of power by the military ${ }^{1}$. Essentially similar reasons have motivated the constitution of single party systems. In most cases, the emergence of single party rule in decolonized polities was preceded by a custodial period of political development during which a competitive party experiment transpired under custody of an organized progenitor or progeny of the decolonizing experience. Constitutionally democratic, nominally plural and competitive, these interim party systems were functionally hegemonic ${ }^{2}$ in that the governing party had no nationally articulate or effective rival.

The practice has been to classify party systems of this kind under the rubric "one party dominant". It may be more useful analytically to refer to them as custodial party systems and to concieve of the dominant party as being a custodial party since these references are more generically specific. The term custodial conveys the fact of trusteeship which a custodial party holds and it underscores its commission of a public obligation for the development of the new nation. It implies, as well, the fact that one party exercises mastery over an emergent party and political system, though it suggests that that advantage is an expedient to be dispensed with as the developing society matures. The connotation also suits the inherently dynamic quality of custodial party systems which are, in essence, pulled in opposite directions by an internal dialectic. On the one side, they are charged to become more truly democratic and competitive. On the other, they are impelled toward the perfection of the single party form.

Of the two tendencies, the single party drive seems to be the more compelling. What research on the emergence of single party systems in decolonized polities reveals is that, in general, the appearance of two organizational faults in the political system is causally operative in the transition from custodial to single party rule. First is a failure to generate and mobilize the political power needed to make

\footnotetext{
1 A comprehensive view of the military role is provided in John J. Johnson (ed.), The Role of the Military in Underdeveloped Countries, Princeton University Press, Princeton, 1962 and Morris Janowitz, The Military in the Political Development of the $\mathrm{New}$ Nations, University of Chicago Press, Chicago, 1964. See also Amos Perlmutter, "The Praetorian State and the Praetorian Army", Comparative Politics, Vol. I, No. 3 (April 1969), pp. 382-404.

2 The idea of hegemonic and turnover party systems is developed in Joseph La Palombara and Myron Weiner, "The Origin and Development of Political Parties" in their edited Political Parties and Political Development, Princeton University Press, Princeton, 1966, pp. 33-41.
} 
the complex machinery of government work efficiently and effectively. Related to this is the manifestation of threats to national unity due to the widening of regional, ethnic, tribal, communal, or other group cleavages ${ }^{3}$.

The inclusiveness of custodial parties and their proclivity to identify themselves with the nation tends to obscure the distinction that might exist between faults in the political system and those which may arise within the custodial party itself. That party interest is implicated in the decision to transit to single party rule, however, is evident. The move seems to occur when internal management problems in the custodial party become intense; when, more specifically, faction in the party endangers its governing majority and when the vertical linkage of the party is impaired by the pull of related centrifugal tendencies at lower levels where popular support is mobilized.

The circumstance conducive to the converse development of custodial party systems is less clear. While empirical and theoretical work on party system morphology is helpful, the evolvement of competitive from custodial party settings has not been critically examined, partly because the phenomenon is so rare. One of the few decolonized polities to experience such an evolvement is Sri Lanka ${ }^{4}$. Achieving independence in 1948, Sri Lanka was governed for eight years thereafter by a custodial party system dominated by the United National Party. A single party trend became particulaly evident after the election of 1952 returned the party with a majority sufficient to alter the constitution. The tendency was arrested when four years later an oppositional coalition headed by the Sri Lanka Freedom Party received a popular mandate. That event marked the emergence of a workable, competitive party system which over the years since has succeeded in aligning popular and parliamentary majorities. There is strong evidence to suggest that the integration of the Ceylonese political system is a product of the alternative government capability provided by Sri Lanka's competitive party system.

The Ceylonese experience is not dissimilar to the custodial party periods of post-independence politics in the United States and Canada. Of the American case, Seymour Martin Lipset has observed that during the early years after independence ". . . it was touch and go whether the complex balance of forces would swing in the direction of a one- or two-party system, or even whether the nation would survive as an entity ${ }^{\text {" }}$. The biparty pattern was not confirmed until the custodial period of rule by the Federalist Party was cut short by a presidential election aptly referred to by Thomas Jefferson as "The Revolution of $1800^{\prime \prime}$. The issue in that critical election, Joseph Charles says, was

3 Reasons for the emergence of one party systems in new states are discussed in Rupert Emerson, Political Modernization: The Single-Party System, University of Denver Monograph Series in World Affairs, No. 1, 1963-1964, Lucien W. Pye, Aspects of Political Development, Little, Brown and Co., Boston, 1966, Rupert Emerson, "Parties and National Integration in Africa" in La Palombara and Weiner, Op. Cit., pp. 267-302, Ralph R. Premdas, "Towards a One-Party System in Papua New Guinea: Some Problems and Prospects", Australian Outlook, Vol. 29, No. 2 (August 1975), pp. 161-179, James S. Coleman and Carl G. Rosberg Jr. (ed.s), Political Parties and National Integration in Tropical Africa, University of California Press, Berkeley, 1964 and Immanuel Wallerstein, "The Decline of the Party in Single-Party African States" in La Palombara and Weiner, Op. Cit., pp. 201-214. See also Samuel P. Huntington and Clement H. Moore (ed.s), Authoritarian Politics in Modern Society: The Dynamics of Established One-Party Systmes, Basic Books, New York, 1970. An attempt to theorize democratic evolvement is Dankwart A. Rostow, "Transitions to Democracy: Toward a Dynamic Model", Comparative Politics, Vol. 2, No. 3 (April 1970), pp. 337-363.

4 The evolution of Ceylonese parties is analyzed in my The Growth of a Party System in Ceylon, Brown University Press, Providence, 1969.

5 The First New Nation, Doubleday and Co., Inc. (Anchor Books), New York, 1967, p. 18.

6 Quoted in Morton Grodzins "Political Parties and the Crisis of Succession in the United States: The Case of $1800^{\prime \prime}$ in La Palombara and Weiner, Op. Cit., p. 318. 
not merely whether or not a political opposition was to be allowed to exist. "The more important point was whether or not, when a political opposition had been successful at the polls, the choice of the voters was to be followed?."

The struggle to effect the Confederation of Canada was more contentious than the constitutional debate that led to the union of the states, but post-independence politics in Canada was not as bitter and exacerbated as was that in the democracy to its south. The survival of the democratic order was also not at stake, though the long tenure held federally by the Liberal-Conservative Party 8 acted as a serious, practical constraint on the development of competitive party politics at the level of the Dominion. Formed in 1854, the coalition of farflung forces molded into a more stable alliance by the leadership of Sir John A. Macdonald held power for a total of thirty-eight years, falling from office from 1873 to 1878 because of the notorious Pacific Scandal. Competitive party politics federally in Canada dates from 1896, the year considered by Gwendolen M. Carter to mark "the most significant watershed in Canadian politics . . .9". In the election of 1896 the Ontario-Quebec axis ${ }^{10}$ of Macdonald's party broke, the Liberal Party won power for the first time as a cohesive unit, and "the golden age of the two party system" was inaugurated. The event occurred at a time when the biracial fabric of the confederation had worn thin and when the resurgence of a strong "provincial rights" movement was placing provinces in direct opposition to the centralized constitutional structure imposed by political developments in Ottawa. The victory of the Liberal Party in that election evinced the capacity of the party system to respond in a positive way to an alienated decentralizing alignment, and the regrouping enterprise served the integration of the Canadian political system.

A comparative investigation of these three cases suggests some conclusions which are analytically provocative. Comparisons indicate, for example, that the same organizational break-down causally manifest in the rise of single party systems from custodial party backgrounds may also be an impetus to the generation of competitive party systems. Moreover, the effect of the competitive bent taken by the party systems at the close of the custodial period in these three cases was restorative in regard to the system as a whole. Not only did the transition entail a vital reintegration of important political units; there is a distinct possibility that centrifugal tendencies might have intensified and became damaging had the custodial party remained in power. In these cases, therefore, the emergence of a competitive party system had the effect of healing a political infirmity which in the majority of instances provides the raison d'être for single party rule. Finally, the advent of competitive party systems in the North American democracies and Sri Lanka represented a significant advance in political development for, in addition to reaffirming strong central government, it involved the direct organization of voters in national political contests.

\footnotetext{
7 The Origins of the American Party System, The Institute of Early American History and Culture, Williamsburg, 1956, p. 9. For a discussion of the same point see Richard Hofstadter, The Idea of a Party System, University of California Press, Berkeley, 1970.

8 It was not until after 1878 that the party gradually became known as the Conservative Party.

9 "The Commonwealth Overseas: Variations on a British Theme" in Sigmund Neumann (ed.), Modern Political Parties, University of Chicago Press, Chicago, 1956, p. 63.

10 Quebec, of course, was French while Ontario was predominantly English. The political alliance of the two provinces was essential to biracial unity and between them, by 1896, they held 157 seats in a House of Commons consisting of 213 members.
} 
The following discussion represents a attempt to clarify the process by which competitive party systems emerge from custodial party settings. The focus of the enquiry is on the custodial party experience of Canada, the United States and Sri Lanka, and of central concern is the organization, break-down and turn-over of custodial parties. Fundamentally, the findings of the paper support the contention, most recently and ardently advanced by La Palombara and Weiner ${ }^{11}$, that democratic party systems are more inclined to develop when a legislative arena acts as the womb of party emergence and when competition within it provides impetus for the organizational growth of parties.

\section{The Generation of American, Ceylonese and Canadian Parties}

Governmental imperative figured strongly in the formative party period in Canada, the United States and Sri Lanka. The original American parties, William Chambers observes, emerged in part "in response to the problems leaders faced in trying to operate...complex governmental machinery effectively ${ }^{12}$ ". Canadian parties had a similarly symbiotic genesis; developing, in the words of one study, "out of the need to provide government ${ }^{13}$ ". In Sri Lanka, the origin of Marxist parties was extra-parliamentary; that of other durable parties related to the constitutional reform which granted statehood, the institution and operation of the parliamentary system. The UNP was formed specifically to mobilize popular and government majorities in order to make the new political system work. The SLFP was organized in 1951 by S. W. R. D. Bandaranaike who with others at that time split from the UNP. Its purpose, Bandaranaike said, was to provide a democratic alternative to the UNP; to enable people who were dissatisfied with the policies and programs of the Government an opportunity "to make a change that was neither revolutionary or extreme... ${ }^{14 "}$.

Another similarity in the generation of parties in these countries is the lag that existed between the attainment of independence and the enrootment of party politics. While parties or party-like groupings were in evidence even before statehood was achieved, the first governments of Canada, Sri Lanka and the United States were fundamentally ministerialist. The confederation of Canada, Escott M. Reid notes. "saw group government established at Ottawa".

Macdonald headed two ministerialist coalitions and then Alexander Mackenzie put one together in 1873, remaining Prime Minister until 1878. Parliamentary alignments were not firm; the practice of "crossing the floor" and uncontested elections made it "sometimes not possible to tell which party had won an election until the first division in parliament when the 'loose fish', the 'shaky fellows' and the 'waiters upon Povidence' had decided which party it was in their own and their constituency's interest to support ${ }^{16}$ ". The custom was modified by

11 "The Origin and Development of Political Parties", Op. Cit. The same point was earlier argued by Maurice Duverger, Political Parties, Methuen and Co., Ltd., London, 1962.

12 "Parties and Nation-Building in America", in La Palombara and Weiner, Op. Cit., p. 84.

13 F. C. Engelmann and M. A. Schwartz, Canadian Political Parties: Origin, Character, Impact, Prentice-Hall of Canada, Ltd., Scarborough, 1975, p. 50.

14 Ceylon Daily News, December 29, 1952

15 "The Rise of National Parties in Canada", in Hugh G. Thorburn (ed.), Party Politics in Canada, Prentice-Hall of Canada, Ltd., Toronto, 1963, p. 16.

16 N. J. Miners, "Floor Crossing and Pork-Barrel Politics in New Nations", Parliamentary Affairs, Vol. XXV, No. 1 (Winter 1971/72), p. 17. 
the holding of simultaneous elections and the introduction of the secret ballot in 1874 , though it was not until after 1878 that strict party discipline became the rule ${ }^{17}$. In the same year began the long eighteen year period of Conservative rule during which party division solidified electorally, as well as in parliament, and the Conservative Party became a consolidated unit ${ }^{18}$.

American parties initially became visible toward the end of George Washington's first term in office in spite of the explicit denunciation of party spirit by leaders who themselves became the great architects of party. By the early 1790's party lines had hardened in Congress ${ }^{19}$, but it was not until 1796, according to Manning J. Dauer, that the "growth of party spirit had reached the point that the demand (electorally) was for party men ${ }^{20}$ ". The Federalists crystalized gradually; evolving from a majority faction into party. As policy was legislated, William Chambers says, strong responses were evoked across the country and in the process "what began as a capitol faction soon assumed status as a national faction and then, finally, as the new Federalist party" ${ }^{21}$ ".

Party label did not become electorally meaningful on a large scale in Sri Lanka until the election of $1956^{22}$. In the elections of 1947 and 1952 Marxist parties drew partisan support from voters and by 1952 the UNP had become a strong, visible entity electorally. That election marked a significant advance over the previous one when voting behaviour was extremely personalistic and the UNP was electorally so embryonic that in several constituencies UNP candidates contested each other. The first government formed by the UNP was in reality ministerialist. Not only did the party give its label to an excessive number of candidates hoping that most would be likely to succeed; it also had to mobilize a coalition government because the election did not return it with the parliamentary majority it had expected. It easily attracted the support of a large number of independent members of parliament, however, and it arranged a parliamentary alliance with the Tamil Congress. It also profited from the constitutional provision which permitted the appointment of six nominated members to parliament. Though crossing the floor was a common practice, the UNP kept fairly disciplined ranks $^{23}$ and its control of government was never in jeopardy during the first two terms it held office.

\section{Custodial Parties and the Organization of Government}

The essential attribute of custodial parties in each of these cases was the manifest capacity to respond successfully to the organizing imperatives of central governmental institutions. In Canada and Sri Lanka, mastery of the governing mecha-

\footnotetext{
17 Engelmann und Schwartz, Op. Cit., p. 50.

18 Party development was slow to develop in western Canada and it was not until 1896 that the two major Canadian parties became national. F. H. Underhill, "The Development of National Political parties in Canada", Canadian Historical Review, Vol. XVI (1935), pp. 367-387.

19 J. C. Miller, The Federalist Era, Harper and Row, New York, 1960, p. 123.

20 The Adam's Federalists, John Hopkins Press, Baltimore, 1953, p. 34.

21 Parties in a New Nation, Oxford University Press, New York, 1963, pp. 39-40. See also Paul Goodman, "The First American Party System", in William N. Chambers and Walter Dean Burnham (ed.s), The American Party Systems, Oxford University Press New York, 1967, pp. 56-89.

22 For an analysis of evolving electoral behaviour in Sri Lanka see Calvin A. Woodward, “Sri Lanka's Electoral Experience: From Personal to Party Politics", Pacific Affairs, Vol. 47, No. 4 (Winter 1974-1975), pp. 455-471. See also A. Jeyaratnam Wilson, Politics in Sri Lanka, 1947-1973, Macmillan, London and Basingstoke, 1974, especially pp. 125-188.

23 W. Howard Wriggins was highly impressed by this. Ceylon: Dilemmas of a New Nation, Princeton University Press, Princeton, 1960, p. 108.
} 
nism entailed the stabilization of a parliamentary majority; in the United States the custodial party had the additional task of linking a legislative majority to the executive power. What further defined custodial parties in these cases was the fact that they became almost exclusive agents of the central government authority. Not only was their objective the provision of effective and stable government, but also the priority of each one of them was the creation of a powerful central control.

The Federalist Party emerged as the first stable majority opinion to be expressed by the political elite whose labor had forged the union of states. Alexander Hamilton was the great party-builder; the strategist and tactician who solidified a Congressional majority, related it to Administration policy and leadership and, in the process, surmounted the institutional separation of power innately impedimental to government. The Federalist Party, Chambers says, was pre-eminently a "government party" which perceived of itself as "a party of stability, dedicated to the idea that the first imperative for a government in a new nation was that it must govern and sustain itself ${ }^{24}$ ". The UNP saw its mission in almost exactly the same terms. Its vital purpose, as one of its founding members said, was to give Sri Lanka "that stability of Government which was needed particularly at the beginning of a new era of freedom ${ }^{25}$ ".

In Canada the ability of the Conservative Party to forge stable government depended on Macdonald whose "greatest talent", R. MacGregor Dawson says, "was his genius for conciliation"26". G. M. Hougham also considers the Conservative success to have been largely a one man show. "Through his personal magnetism", he writes of Macdonald, "through his ability as a conciliator of individual and group antagonisms, and through his readiness to utilize the power and patronage of the national government when necessary, Macdonald preserved a semblance of unity among the disparate elements of his party ${ }^{27}$ ".

The success of these parties enhanced the quality of the central government simply by making it work. In addition, however, each custodial party embarked on a nation-building, centralizing programme that defined, extended and consolidated the authority of the central government power. The Conservative Party pursued that under the slogan of the "National Policy" and in regard to the Federalists it was embodied in such Hamiltonian measures as Assumption, Funding, the establishment of the Bank and commercial policy. "Each party", Dawson says of the two custodial parties of the North American democracy, "was the party of centralization; each believed in identifying itself with the propertied, commercial and industrial interests; each used these interests to advance nationalist as against local causes, and received in return the powerful support which they could give28" The main concern of the UNP was to ensure the viability of the democratic order in the face of grave internal threats to that which it perceived to exist. Defense agreements, the building of armed forces, a public security act, the regulation of trade union activity, the control of Indian immigration and citizenship laws, and other private and public acts all derived from an attempt to secure the

\footnotetext{
24 Parties in a New Nation, p. 65.

25 Spoken by Bandaranaike, House of Representatives, Debates, Vol. X, col. 698.

26 The Government of Canada, University of Toronto Press, Toronto, 1956, p. 494.

27 George M. Hougham, "The Background and Development of National Parties", in Thorburn, Op. Cit., p. 5.

28 Op. Cit., pp. $493-494$.
} 
political environment. Economically, the policy of the UNP government asserted the authority of a public sector and was designed to obtain, according to W. Howard Wriggins, "a substantial transfer of income and economic power from foreign hands to Ceylonese". Through taxation policy and market controls, Wriggins continues, the UNP tried "to substitute a considerable measure of government decision for private sector decision; particularly at the beginning of their rule ${ }^{29}$ ".

The establishment of a national authority was not only the design of custodial party rule. National unity was also a natural byproduct of the same political majority which enabled custodial parties to respond successfully to the organizing imperatives of government. The network of notables which custodial parties constructed at the vital center of the political system acted as a concourse through which the wider periphery of the political system was pulled into a working, productive association with the center. The Federalist majority in Congress by itself implied that consensus. Those elected in congressional contests were local notables who represented the voice of myriad constituencies; a majority of them voiced a national expression. Custodial parties in Canada and Sri Lanka were omnibus. The UNP was an impressively comprehensive vehicle founded by leaders of all the important communal organizations on the Island. Its intercommunal articulation expanded when in the first year of independence it formed a parliamentary alliance with the TC. The UNP was in reality a center pivot around which gravitated political notables of various shades; a "coalition party" as Bandaranaike once described it. National unity inhered in the organization of the party itself which, in the First Parliament, embraced nearly all elected democratic elements.

The Conservative Party of Macdonald was also a coalition of diverse, potentially divisive groups; a "composite party", in the words of Alexander Brady, which "drew under a single political roof a medley of Canadian interests ${ }^{30}$ ". In governments it formed, Macdonald was able to persuade such stalwart anti-confederationists as Joseph Howe to join and that, more than anything, helped to prevent the formation of party lines on the issue of the confederation itself. As importantly, Conservative governments drew support from Catholic, Protestant, urban, rural, English and French constituencies and found thereby, according to one authority, "the standard formula for the construction of a national party in Canada" ${ }^{31 "}$.

These custodial parties also had a decisive influence on their oppositions. The major opponent of each of them coalesced slowly, developing an identity as it reacted to the administration of the custodial party. "Division into parties cannot be studied apart from administration policy ...", Charles says of the American experience. It was in reaction to the centralizing policies of the Federalists, Charles continues, "that some of the ablest Republican leaders went into open opposition, and it was their stand against these and other government policies which brought them most of their followers"32". Personal rivalries, "sometimes

29 Op. Cit., p. 117

30 Democracy in the Dominions, University of Toronto Press, Toronto, 1955, p: 98.

31 Hougham, Op. Cit., p. 2. Hugh McD. Clokie argues that the “chief basis of union" within Canadian parties has been allegiance to the party leader. Canadian Government and Politics, Longmans, Green and Company, Toronto, 1944, p. 90.

32 Op. Cit., p. 91. 
as petty as they were colourful ${ }^{33}$ ", were also involved. Similar animosities played their part in the split of Bandaranaike's faction from the UNP; he in particular was embittered by having his ambition for leadership frustrated by manoeuverings in the party hierarchy. The traditionalist orientation of his party was explicitly intended to exploit dissatisfaction with the westernized orientation of UNP rule. In Canada, the Liberal party only gradually evolved a program. Over the years, however, it "became more and more the instrument of a 'provincial rights' opposition to Tory nation-building and centralization ${ }^{34 "}$.

\section{Custodial Parties and the Organization of the Electorate}

In the Ceylonese, Canadian and American experience, original organizational innovations at the level of government were the work of custodial parties; political organization electorally was advanced by pioneering initiatives of opposition parties. Referring to the presidential contest of 1800 , Noble E. Cunningham Jr. explains "the widespread Republican initiative in party organizing" by the need to overcome "a disadvantageous position ${ }^{35}$ ". Republicans had earlier formed "democratic societies" locally but were persuaded to disband these and to suspend the construction of oppositional committees out of deference to Washington. Even so, emergent Republican societies made themselves felt by 1794 , according to Dauer, when "Republican strength clearly began to encroach on that of the Federalists in the cities and towns ${ }^{36}$ ". Within six years the party was able to field an effective organization and Cunningham considers this to be one of "the keys to Republican success in the election of 180037 ".

The Liberal Party advanced provincially in Canada but the federal unit did not significantly progress until Sir Wilfred Laurier assumed its leadership in 1887. It was he who inspired the holding of a national convention in 1893, the first ever convoked by a federal party in Canada. The convention, J. M. Beck says, "by assembling nearly every important Liberal in the Dominion, completed the forging of a loose alliance of provincial parties into a coherent, national organization ${ }^{38}$ ". The party also built a prodigious political machine in Quebec, until then an almost exclusive domain of an anti-Liberal establishment which worked in alliance with the Conservatives. Here the great Liberal party builder was J. I. Tarte, formerly a "Quebec lieutenant" of Macdonald. By 1894, Beck comments, Tarte "had perfected the basic central organization and had turned his attention to the lower levels ${ }^{39}$ ". When the Liberals took Quebec, which in the critical election of 1896 gave them a majority nationally, no small debt was due to the work of "political clubs" which were active everywhere in the province on behalf of the party.

\footnotetext{
33 Chambers, "Parties and Nation-Building in America", p. 81.

34 Hougham, Op. Cit., p. 5.

35 The Jeffersonian Republicans, University of North Carolina Press, Chapel Hill, 1957, p. 149. V. O. Key has argued that "Party organization developed first among the outs who sought to replace the established holders of authority". Politics, Parties and Pressure Groups, Thomas Y. Crowell, New York, 1958, p. 223.

36 Op. Cit., p. 19.

37 Op. Cit., p. 259.

38 Pendulum of Power: Canada's Federal Elections, Prentice-Hall of Canada, Ltd., Scarborough, 1968, 39 Ibid., p. 82 .
} 
The SLFP did not perceptively grow from its formation in 1951 until the election of 1956. It did, however, formulate a manifesto designed to appeal to the traditionalist majority in Sri Lanka. On the eve of the election of 1956 it was instrumental in forging the Mahajana Eksath Peramuna, a wide ranging coalition of notables and "political intermediaries" who were locally influential with voters. Bandaranaike then concluded no-contest arrangements with Marxist parties so as to unite the anti-UNP vote in constituencies. Without these devices, the UNP probably would have been returned in the election instead of suffering a rout. These techniques have remained important to the electoral success of the SLFP and similar ones have since been adopted by the UNP.

Organizational up-dating fell by default to opposition parties largely because in these cases custodial parties were aloof to changing political needs. An investigating committee appointed by the UNP after its defeat was frank to admit that ${ }^{40}$; similarly, Hamilton in 1801 said that the Federalist Party had "erred in relying so much on the rectitude and the utility of their measures as to have neglected the cultivation of popular favor, by fair and justifiable expedients ${ }^{41}$ ". The Conservatives lost Quebec in 1896 because of the upsurge of a mass movement they only belatedly recognized and probably could not have managed; partly because their vision was blurred and their political techniques determined by a certain "tory touch ${ }^{42}$ ". An aristocratic notion of the political vocation ran strong in the vein of the UNP leadership, retarded the organizational growth of the party and was translated by opposition rhetoric into the charge that the UNP presumed a divine right to govern. E. E. Schattschneider is of the opinion that the Federalist Party divined for itself a permanent control of government and that this is one reason why it failed "to develop an organization in the electorate at large ...43".

These custodial parties were also dissuaded from engaging in creative enterprise by the fact that their political strategy and organization were a proven investment. Structurally resembling what Max Weber termed "parties of notables"4", each of these custodial parties depended organizationally on the government power it held and on the apparatus of the state. Party decisions were made in caucus or cabinet, patronage and the pork barrel were used to firm party ranks. "As the party in power", Cunningham writes of the Federalists, "they controlled the federal patronage, and they were not disinclined to use this power to entrench themselves in office . . .45". The Conservative Party was built through the careful use of "the patronage and power of office ...4"; by a willingness, it was said, "to buy love and purchase peace 47 ". It also was not disinclined to employ the public service for partisan ends. There is evidence, for example, that in electoral politics

40 For a discussion of its findings see Woodward, The Growth of a Party System in Ceylon, p. 187.

41 Quoted in Charles, Op. Cit., p. 8.

42 G. Horowitz, Canadian Labour in Politics, University of Toronto Press, Toronto, 1968, p. 20.

43 "United States: The Functional Approach to Party Government", in Neumann, Op. Cit., p. 196.

44 "Politics as a Vocation", in H. H. Gerth and C. Wright Mills (ed.s), From Max Weber, Oxford University Press (Galaxy Books), New York, 1958, pp. 77-128. Lipset says that the organization of the Federalist Party "could be described as parallel to those patron parties in Africa that are national but which represent a linking of local notables to mobilize the common people”. Op. Cit., p. 37.

45 Op. Cit., p. 148.

47 Quoted in Donald G. 5 . Creighton, Dominion of the North, Houghton Mifflin Co., Boston, 1944, p. 327. 
"civil servants and government contractors felt the need to transform their dependence on the Government into political support ${ }^{48}$ ".

The prerogatives of office were indispensable to both the party and nation building missions to which the UNP applied itself during its custodial rule. Its recruitment of a stable government was contingent upon the creation and careful dispensation of ministerial portfolios and position; the number established being in excess of half the party members elected to the First Parliament and more than one-third of the governing coalition it subsequently enjoined ${ }^{49}$. The formal organization of the party was neglected and for a number of reasons its development was not forced. Electorally, the UNP relied upon a potent and intricate network of personal influence structures. In addition to the communal organiza tions associated with the party and its cluster of locally influential intermediaries attached to it through the notables it nominated for election, the UNP enlisted the highly centralized government service to enrol the support of voters. That and the use of other public facilities caused the Opposition repeatedly to condemn the UNP for, in the words of one indictment, "its utilization of the machinery of government for party political ends ${ }^{50}$ ". There is also evidence of "pay-offs" to constituencies loyal to the party, and it seems true that some candidates of the party threatened the withdrawal of vital government allotments to constituencies not in support of the party.

The aegis and public apotheosis of a charismatic leader were supremely important in the success of each of these custodial parties. Hamilton was unequivocal in his praise for the utility of Washington; Macdonald's image was vital to his party's draw in French Quebec, and D. S. Senanayake, in addition to his appeal to the Sinhalese majority, was trusted by minority communities. These custodial parties also held office during relatively good times and the effect of their administration was generally profitable to most groups. In addition they were able to capitalize on a certain measure of national good will. The independence achieved by Sri Lanka was uplifting to national pride and, in Canada, "the policies developed by the Conservative administration reflected and reinforced a burgeoning national spirit in the Dominion ${ }^{51}$ ". Hamilton was advised to expedite the legislatation of his fiscal programme before good feeling in the states waned. "The present Period", an associate wrote to him in 1789 , "is very favorable for carrying into Effect a System of Taxation, as the Affection of the People are so rivetted to the New Government, that their minds will be easily conciliated to all its operations ${ }^{52}$ ".

\section{The Break-Down of Custodial Parties}

These custodial parties, by the time of their turn-over by alert, politically astute oppositions, were no longer powerful, adroitly managed entities. Of the UNP, it was said in 1956 that it was neither united nor national nor, as a consequence of its defeat, even a party. Since the preceding election, its alliance with the TC

\footnotetext{
48 Engelmann und Schwartz, Op. Cit., p. 5. The Liberal Party, on the other hand, refused to employ the power of office for party ends. Underhill, Op. Cit., pp. 383-384.

49 Wriggins, Op. Cit., p. 115 and Woodward, The Growth of a Party System in Ceylon, p. 73.

50 Quoted in Ibid., p. 94.

51 Hougham, Op. Cit., p. 6.

52 Quoted in Charles, Op. cit., p. 22.
} 
had broken down and many notables had resigned from the Government and the party. The defeat of the UNP was quite clearly a function of its own disorganization as much as it was the result of the remobilizing genius of its oppositions. A trail of internal troubles similarly preceded the downfall of the Conservative Party in Canada in 1896; by the time Sir Charles Tupper assumed the party leadership in January of that year it had become very difficult, John Saywell writes, to "restore the inward harmony or outward presence of the Conservative Party ${ }^{53}$." Prior to its defeat, the Federalist Party had been wrent by an increasingly bitter debate between factions committed to Adams and a largely Hamiltonian section of the party known as the "High Federalists". This split in Federalist ranks, Grodzins says, "contributed greatly to Jefferson's becoming President in the election of 180054."

In each case, internal managerial problems in the custodial party did not become intense until death or retirement removed charismatic headship from the party. So long as Washington provided a shield, it did not matter that much that the machinations of Hamilton, in Charles' words, "divided his erstwhile supporters while it united his opponents ${ }^{55}$." In like vein, W. Howard Wriggins is convinced that the popularity of D. S. Senanayake, especially his ability to appeal strongly to traditionalist as well as westernized elements, was such as to nullify the immediate, potentially damaging impact on the UNP of Bandaranaike's defection in 1951. Moreover, as long as Senanayake survived, Wriggins says, "his stature in relation to all his party colleagues was such that faction was kept to a minimum ${ }^{56}$." Macdonald was for similar reason an irreplaceable asset to the Conservative Party. Not only were his pre-eminence and personal gifts essential to co-operation in the party hierarchy; after his death it was evident that "there was not a single English-speaking Conservative in which French Canada could confidently put its trust ${ }^{57}$."

The beginning of the break-down of these custodial parties was manifest in the destructive leadership battles that ensued in party circles once the office of headship was vacated. Hamilton became implacable and never fully accepted Adams' succession to the presidency. He refused to support him in the presidential campaign of $1796^{58}$ and his personal disappointment underscored contentions regarding policy which festered and became debilitating to the party as the election of 1800 approached. When Macdonald died in 1891 Tupper, whose ability made him heir apparent, was denied the mantel by the Cabinet; partly, it has been suggested, because "small men did not want a big leader ${ }^{59}$." Within a five year period the reins of leadership were held by several hands, none of which had the stature or sensitivity to keep intact the fragile coalition of diverse forces from which the party drew strength. Less tolerant toryism surfaced in Ontario, the Quebec contingent became disheartened and aggrieved, and the leadership battle, culminating in the high level "Nest of Traitors" incident which tore apart the party command, obtained truce only shortly before the election of 1896.

53 "The Crown and the Politicans: The Canadian Succession Question", Canadian Historical Review, XXXVII (December 1956), p. 331.

54 Op. Cit., p. 314.

55 Op. Cit., p. 35.

56 Op. Cit., p. 114.

57 Beck, Op. Cit., p. 81.

58 Grodzins, Op. Cit., p. 312.

59 Quoted in Lowell C. Clark, “The Conservative Party in the 1890's", Report of the Canadian Historical Association, 1961 , p. 60. 
A comparable succession crisis severely disrupted the UNP after Senanayake suffered a fatal injury in an accident in 1952. Described by one of the leading participants as the "Premier Stakes", the struggle to succeed had been an ongoing undercurrent of concern since the party formed, Bandaranaike being the first casualty of inner-party maneuvering for the position. In accord with the fallen leader's wish, the party selected his son Dudley to succeed him. Popular with the party rank and file, held in warm regard by national opinion, the younger Senanayake's accession nonetheless enraged a section of the UNP allied with Sir John Kotelawala who himself sought the leadership post. For a variety of reasons, Dudley Senanayake was unable to enkindle the stamina or the will demanded of him by circumstances at that time; shaken deeply by a hartal in 1953, believed by some to have been engineered by his opponents in the party, he resigned. Power passed to Kotelawala who was not inclined to conceal his prejudices or to suffer, no less accomodate, differing opinion. Quick of temper, a protagonist of extreme positions on party and political matters, Kotelawala's personal style of leadership led to a series of defections from the party, drained its spirit, and reduced its potential to confront the opposition arranged against it in 1956, a great deal of which were remobilized forces detached from the UNP.

It is noteworthy that internal disturbances, even ruptures, in these custodial parties did not appear to be fatal from the vantage of the central party command. Governing majorities were not imperiled and each remained strong in its control of government. Internacine battle, however, took a heavy toll at lower party levels where the notable structure of custodial parties made them most vulnerable to break-down. It was here that occurred the less perceptible movement of personnel and their voter-retinues from these custodial parties and it was this erosion that provided the opportunity for the remobilizing efforts of opposition parties. In regard to the American case, Charles notes how the Republicans were undoubtedly strengthened by the enrolment of ex-Federalists such as John Dickinson, Charles Pickney and John Langdon among others. "Probably more important", Charles argues however, "in the eventual Federalist defeat than open defection of such leaders as these was the Federalist loss ... of many less prominent men who had nevertheless been the backbone of the party60". Dislocation of the same kind is what undermined the UNP. Defections at the level of government were numerically minor but each carried with it a segment of voter support and an important host of political intermediaries the significance of which Wriggins observed and almost uniquely predicted.

It was in the Quebec section of the Conservative Party that this process of lower level decay was of most consequence in regard to the party's defeat in 1896. The leader of the party there was J. A. Chapleau who had worked closely with Macdonald. Leadership turnings after Macdonald's death resulted in Chapleau being denied a particular cabinet portfolio he desired and he, as well, became resentful of a government "where on questions vitally affecting his province he was not recognized as the man who spoke for Quebec ${ }^{61}$ ". When the election of 1896 approached he refused to work for the party and the Conservatives

60 Op. Cit., pp. $116-117$.

61 H. Blair Neatby and John T. Saywell, "Chapleau and the Conservative Party in Quebec", Canadian Historical Review, XXXVII (March 1956), p. 17. 
entered the contest without an effective organizer in Quebec. Moreover, Tarte, who was the architect of the Liberal victory in the province, had performed similar services for the Conservative Party before his defection some years earlier.

The internal disorganization of these custodial parties had disunifying implications for the larger political system. In each case it meant that the broad political coalition which the custodial party enclosed and on which national unity depended had become estranged. Critical sectors of the population had become alienated; the French in Canada, the traditionalist majority in Sri Lanka, and variegated state factions, mostly the democratic element, in the United States. Additional strain on national unity stemmed from the fact that these oppositions directly challenged the power of the central authority. In the North American cases oppositions were explicitly decentralist; in Sri Lanka, the legitimacy of the national authority and political institutions were at issue in the struggle of traditionalist forces to wrest control from a westernized, Christian elite.

The overall effect of opposition parties in the tense, divisive period embracing the break-down of these custodial parties was restorative. What they did in these three instances was to deflect emergent dissent from the institutions of the central power to the stewards; and, at the same time as they reorganized disaffected groups into a reformist majority, they harnessed potentially disunifying tendencies. Originating in institutions of government, developing in the electorate at-large, moderate ideologically and organized nationally, these opposition parties strengthened the government structure built by custodial parties by giving it a popular base directly committed to it.

In the emergence of competitive party systems from custodial periods in Canada, the United States and Sri Lanka, a complexity of factors is undoubtedly involved. Lipset lists a number of variables which bore importantly on the American experience ${ }^{62}$, and circumstances unique to both Canada and Sri Lanka could be cited. These need to be explored to explain fully the competitive bias taken by custodial party systems in these three cases. What this paper has shown is that the organizational responsiveness of parties was a critical aspect of the process. The system of government worked because of the organizational response of custodial parties, while that of opposition parties was essential to the unity of the political system. In the combination of these responses, a popular and efficient system of government became symbiotically enjoined with competitive party politics.

62 Op. Cit., pp. 102-111. 
The Emergence of Competitive Party Systems: Comparative Observations on the Custodial Party Period in the United States, Sri Lanka and Canada

\author{
By Calvin A. Woodward
}

The article introduces the notion of a custodial party system to refer to the one party dominant party systems which usually characterize an initial period of postindependence politics in new states. The tendency of custodial party systems has been to give way to military or one party rule once internal management problems in the custodial party become intense and when national unity and government efficiency become seriously impaired. The emergence of competitive party systems from custodial party backgrounds has been rare. Three cases where this has occurred are Sri Lanka, Canada and the United States; national competitive party systems having emerged respectively in 1956, 1896 and 1800.

The paper examines comparatively the custodial party period in these cases and focuses on the generation of parties, the means employed by custodial parties to mobilize popular and governing majorities, the break-down of custodial parties and their eventual turn-over by opposition parties. The paper finds that politica! techniques used by custodial parties served to ensure governmental stability and national unity during the early years after statehood was achieved, but that the rule of custodial parties caused a reaction to centralization and aroused centrifugal tendencies nationally. In these cases, opposition parties, which electorally were organizational pioneers, harnessed potential separatist forces and formed them into a national majority conducive to both government and national stability. The emergence of a competitive party system in Canada, the United States and Sri Lanka, therefore, was induced by and moderated disunifying manifestations which in most new states have tended to rationalize the abortion of democratic party systems.

\title{
The Desiderative Constitution: A Tentative Outline of a Theory
}

Ву С. Ево

The developing polities are viewed as societies experiencing tension caused by the juxtaposition of sets of primordial structures and values and those typical of industrial societies. The mix of these two incongrous elements often results in a behavioural pattern in which a noticeable gap appears to exist between formally prescribed norms of conduct on the one hand, and actual behaviours, on the other. This highly unstable and volatile co-existence is perceived as one of the basic sources of the chronic crises that have become a conspicuous feature of transitional societies. In this regard, the brief history of Western-style parliamentarism in Nigeria between 1960-1967 provides one with a striking object lesson. Thus, the epochal task facing the developing societies would seem to oblige them to devise ways of achieving a peaceful evolution in the direction of increasing modernity that will allow them to pursue the twin goals of nationhood and rapid social and economic progress unhampered by series of cries and disruptions. This path of advance is visualised as leading from the present stage of "Incorporative dualism“, 